\title{
Esquerdas no Panfleto. A crise política de 1964 no jornal da Frente de Mobilização Popular
}

Jorge Ferreira*

Resumo: Desde o início do governo do presidente João Goulart, partidos, movimentos e organizações de esquerda se uniram em torno de um programa político conhecido como "reformas de base". No início de 1963, sob a liderança de Leonel Brizola, as esquerdas fundaram a Frente de Mobilização Popular (FMP). O grupo nacional-revolucionário que, dentro do Partido Trabalhista Brasileiro (PTB), seguia a liderança de Leonel Brizola tinha o seu jornal: Panfleto, o jornal do homem da rua. Mas Panfleto também era porta-voz da FMP. Por meio de um veículo próprio de comunicação, as esquerdas que reconheciam a liderança de Brizola expressavam suas ideias, seus projetos e suas estratégias. O objetivo do artigo é resgatar ideias e projetos políticos das esquerdas unidas na FMP e publicados no Panfleto entre os dias 17 de fevereiro de 1964, data da primeira edição do jornal, e 30 de março do mesmo ano, quando foi publicado o último número - em um total de sete exemplares. Os dois meses foram críticos na crise que desestabilizou o governo Goulart, com o acirramento do processo de radicalização das esquerdas que lutavam pelas reformas e das direitas que resistiam a sua implementação.

Palavras-chave: Panfleto, o jornal do homem da rua. Frente de Mobilização Popular. Crise política de 1964. Governo João Goulart. Reformas de Base.

\footnotetext{
"Professor Titular de História do Brasil da Universidade Federal Fluminense e Pesquisador do CNPq. Endereço eletrônico: jorge-fer@uol.com.br
} 
Durante o governo de Juscelino Kubitschek, partidos, movimentos e organizações de esquerda cresceram em termos de organização e avançaram em suas lutas. Tendo o nacionalismo como bandeira política, suas propostas reformistas encontraram receptividade em amplos setores da sociedade brasileira.

Embora com diferentes orientações ideológicas, e nem sempre unidas, as esquerdas formaram, no início do governo Goulart, o que Argelina Figueiredo chamou de "coalizão radical pró-reformas" (FIGUEIREDO, 1993, p. 66). No início de 1963, sob a liderança de Leonel Brizola, surgiu a Frente de Mobilização Popular (FMP), qualificada por Ruy Mauro Marini como um "parlamento das esquerdas" (citado em NEVES, 1989, p. 236). Reunindo as principais organizações de esquerda que lutavam pelas reformas de base, a Frente exigia que Goulart governasse apenas com o apoio político dela, desconhecendo outras organizações partidárias, inclusive as de centro.

O movimento estudantil participava da FMP, sendo representado pela União Nacional dos Estudantes (UNE). Em processo de radicalização política desde o início do governo Kubitschek, as lideranças estudantis defendiam a formação da aliança operárioestudantil-camponesa (SALDANHA, 2005). O movimento sindical urbano estava representado pelo Comando Geral dos Trabalhadores (CGT), central sindical que uniu sindicalistas comunistas e trabalhistas. A Confederação Nacional dos Trabalhadores na Indústria (CNTI), a Confederação Nacional dos Trabalhadores nas Empresas de Crédito (CONTEC) e a intersindical Pacto de Unidade e Ação (PUA) também estavam na FMP. Setores das Ligas Camponesas igualmente participavam da Frente. $\mathrm{Na}$ luta pela terra, líderes camponeses defendiam a reforma agrária com ou sem a participação do Congresso Nacional - e daí o lema formulado por Francisco Julião: "reforma agrária na lei ou na marra" ou "reforma agrária com flores ou com sangue". O movimento dos subalternos das Forças Armadas também atuava na FMP. Mobilizados desde o governo Kubitschek, o movimento dos sargentos tomou força com a crise de agosto de 
1961. Marinheiros e fuzileiros da Marinha de Guerra formaram sua própria organização, aderindo à Frente.

Os intelectuais se engajaram no projeto nacionalista e reformista. Diversos deles, junto a artistas, fundaram o Comando Geral dos Trabalhadores Intelectuais, o CGTI, aderindo à FMP. A aliança que se estabeleceu entre a UNE, o CGT, o CGTI, setores das Ligas Camponesas e o movimento dos sargentos, marinheiros e fuzileiros navais abriu novas perspectivas para o movimento reformista. A adesão de organizações revolucionárias fortaleceu ainda mais a frente de esquerda. Entre elas, estavam o Partido Operário Revolucionário (Trotskista) (POR-T) e a Ação Popular (AP). A Frente de Mobilização Popular ainda agregava outras organizações: políticos do Grupo Compacto do Partido Trabalhista Brasileiro (PTB), a Frente Parlamentar Nacionalista (FPN), o grupo político de Miguel Arraes e a ala esquerda do Partido Socialista Brasileiro (PSB).

Um último grupo político que integrava a FMP merece destaque: os nacional-revolucionários, maneira como os seguidores de Leonel Brizola dentro do PTB se autodefiniam. A encampação de empresas norte-americanas e a criação de 680 mil vagas escolares no governo do Rio Grande do Sul, mas, sobretudo, o enfrentamento da direita civil-militar na crise de agosto de 1961, deram a Brizola grande prestígio entre as esquerdas. Identificados como a ala de extrema-esquerda do PTB, os nacional-revolucionários que seguiam a liderança de Brizola, no dizer de Maria Celina D’Araújo, “estavam vivenciando um intenso processo de competição por liderança” dentro do partido, cujo alvo de disputa era o próprio João Goulart. Com a criação da FMP, a competição extrapolou os limites partidários e passou "a centrar na rivalidade com os membros atuantes do PCB” (D’ARAÚJO, 1996, p. 150). Nas sextas-feiras à noite, Brizola falava na rádio Mayrink Veiga. Em associação com emissoras de outros estados, sua voz chegava a praticamente todo o país. A audiência era calculada em 10 milhões de ouvintes (SCHILLING, 1979, p. 219-220). 
Em fins de novembro de 1963, Brizola liderou a formação de "grupos de onze companheiros" ou "comandos nacionalistas". O objetivo mais imediato era organizar os nacional-revolucionários para pressionar Jango e o Congresso Nacional a decretarem as reformas e para resistir a um eventual golpe perpetrado pelas direitas. Com os "grupos de onze", Brizola tinha planos de formar um partido revolucionário sob sua liderança. Segundo avaliação de Marli de Almeida Baldissera, a formação dos "grupos de onze" ocorreu em um momento de "intensa mobilização de ambos os lados, direita e esquerda. $\mathrm{Na}$ defesa de seus interesses, a radicalização política intensificou-se e a capacidade de negociação tornou-se nula" (BALDISSERA, 2005, p. 32).

O Partido Comunista Brasileiro (PCB) tinha uma linha política própria de apoio a Goulart. Contudo, militantes que discordavam da linha adotada pelo partido atuavam na FMP.

Plurais e com propostas nem sempre confluentes, as esquerdas, durante o governo Goulart, conseguiram se unir em uma mesma frente, defendendo um programa comum. $\mathrm{Na}$ avaliação de Lucília de Almeida Neves Delgado, a Frente de Mobilização Popular "se transformou na organização referência de união de todas as forças reformistas que atuaram naqueles anos" (NEVES, 1989, p. 245). Divergências existiam, sobretudo entre lideranças que concorriam no campo reformista. Apesar das dificuldades, a FMP conseguiu congregar organizações, movimentos e partidos de esquerda sob um programa político comum. A Frente exigia que Goulart decretasse imediatamente as reformas de base, entrando em confronto direto com as direitas e os conservadores, incluindo o Partido Social Democrático (PSD). Procurava se impor como força alternativa ao PCB, cuja estratégia era considerada moderada. Segundo Herbert de Souza, o Betinho, na época militante da AP, a FMP foi uma experiência rica para as esquerdas. "Foi uma experiência aberta, um fórum de debates, de articulação, de politização.” (apud MORAES, 1989, p. 259).

Como é comum em organizações de esquerda, o grupo nacional-revolucionário brizolista tinha o seu jornal: Panfleto, o jornal do 
homem da rua. Mas Panfleto também era porta-voz da FMP. Por meio de um veículo próprio de comunicação, as esquerdas que reconheciam a liderança de Brizola expressavam suas ideias, seus projetos e suas estratégias.

Meu objetivo, neste artigo, é resgatar ideias e projetos políticos das esquerdas unidas na FMP, publicados no Panfleto entre os dias 17 de fevereiro de 1964, data da primeira edição do jornal, e 30 de março do mesmo ano, quando foi publicado o último número. Os dois meses foram críticos na crise que desestabilizou o governo Goulart, com o acirramento do processo de radicalização das esquerdas que lutavam pelas reformas e das direitas que resistiam a sua implementação.

\section{A UNE e a aliança operário-estudantil-camponesa}

Em entrevista no primeiro número do Panfleto, o presidente da UNE, José Serra, afirmou que aquele ano seria decisivo para as forças populares, particularmente porque "a contradição entre as necessidades do povo brasileiro e a incapacidade estrutural de satisfazê-las atingirá o ponto mais agudo". ${ }^{1}$ A queda da renda bruta no país e o crescimento demográfico agravariam ainda mais a crise. Segundo sua análise, o grande problema era que existia a alternativa de um "processo radical de transformações sociais", mas o governo não demonstrava interesse em adotá-lo. Para José Serra, "falar em libertação econômica sem falar na encampação, pura e simples, das empresas estrangeiras concessionárias de serviços públicos, é mera pilhéria". Para o presidente da UNE: "procuraremos, por todos os meios, organizar os estudantes e fortalecer a aliança operário-estudantil-camponesa". Outro tema importante era a sucessão presidencial. Neste caso, a opção por Juscelino Kubitschek estava descartada, porque os estudantes não aceitariam "candidaturas conservadoras, ou que se intitulem de centro". Para José Serra, "ou se é a favor ou contra o povo". 
A luta imediata da UNE era pela reforma universitária. Para José Serra, a universidade de elite era alienada. Nela, não existiam "fillhos de operários e de camponeses", nem manifestações da cultura brasileira. "A reforma universitária significará transformar toda a estrutura social do país”, afirmou. Mas, para isso, seria necessária a revisão da Constituição do país: "Entretanto, modificar a Carta Magna, para extinguir a vitaliciedade da cátedra, é tão difícil quanto dar voto ao analfabeto ou abolir o preceito que impede a desapropriação de terras por interesse social. Vamos enviar ao Congresso Nacional uma emenda à Constituição com o objetivo de extinguir a vitaliciedade da cátedra." No entanto, o presidente da UNE não escondia seu descrédito em relação ao Congresso: "não esperamos que o Parlamento vote essas matérias, e sim que se desmascare, mais ainda."

Outro dirigente estudantil, Marcelo Cerqueira, vice-presidente para Assuntos Nacionais da UNE, afirmou, em entrevista ao Panfleto, a necessidade de executar uma política nacionalista para combater o imperialismo e o latifúndio. Goulart deveria decretar imediatamente as seguintes medidas: moratória da dívida externa, monopólio integral da Petrobras, nacionalização da empresa norte-americana Bond and Share, implementação do decreto da SUPRA, reformulação da política econômico-financeira, anistia aos sargentos e legalização do PCB. O presidente, no entender de Cerqueira, deveria estar ao lado da frente de esquerda, mesmo porque os fatos recentes demonstravam "o falecimento da política de conciliação". ${ }^{2}$ Concluindo, ainda afirmou: "no encaminhamento da luta é fundamental a aliança operário-estudantil-camponesa, parcela mais consequente da união das forças anti-imperialistas."

\section{O CGT e o programa sindical}

O segundo número do Panfleto, de 24 de fevereiro de 1964, publicou entrevista com o secretário-geral do CGT, Oswaldo 
Pacheco. Inicialmente, ele defendeu o papel central da classe trabalhadora no processo de transformações por que passava a sociedade brasileira:

O CGT considera, sem menosprezo aos demais patriotas civis e militares, que lutam pelas reformas no Brasil, que a classe operária tomada como agrupamento social em crescente desenvolvimento numérico técnico, de concentração em grandes unidades de produção, como também de conscientização, e capacidade para unir-se e organizar-se com disciplina e comando firme, é uma força destinada a ter papel relevante no processo de lutas pelas reformas e pela libertação econômica de nossa Pátria. ${ }^{3}$

Como programa político para o país, Pacheco exigiu a liberdade de greve, a reforma agrária, a reforma urbana, a implementação do decreto da SUPRA e a elegibilidade para soldados, cabos, sargentos e analfabetos. Como medidas econômicas, acreditava na necessidade de instaurar o monopólio estatal do câmbio e das exportações do café e de ampliar o do petróleo. Também faziam parte do programa do CGT a encampação das refinarias privadas de petróleo e a nacionalização das empresas estrangeiras em "posições-chave em nossa economia", indenizando-as apenas pelo "custo histórico". Segundo Pacheco, as lideranças sindicais estavam dispostas a dar todo o apoio ao governo, desde que ele se decidisse a acabar com a inflação, atacando suas "causas reais", ou seja, o latifúndio e o imperialismo. Sem essas iniciativas, "as medidas superficiais não passarão de meros paliativos que não curarão o doente, mas apenas transferirão o desfecho da crise por alguns meses ou alguns dias". Para o secretário-geral da CGT: "Ao final, prevalecem os pontos de vista das massas populares e que os inimigos, que pareciam fortes e ameaçadores, cederam sempre diante da consciência, unidade e organização do povo.”

Outro dirigente sindical, Aluízio Palhano, vice-presidente do CGT e presidente da CONTEC, em entrevista ao Panfleto, defendeu 
a decretação imediata da reforma bancária, com a democratização do crédito e o direcionamento do sistema bancário para o desenvolvimento econômico do país. ${ }^{4}$ Defendeu também que o dinheiro do povo aplicado nos bancos somente fosse investido em empresas estatais, sem nenhum benefício para as empresas estrangeiras. Além disso, o crédito deveria estar disponível para suprir as necessidades básicas do povo, e não para financiar produtos de luxo. Além dessas medidas, na mesma entrevista, o vice-presidente do CGT afirmou que "a nacionalização dos bancos estrangeiros e o monopólio do câmbio são imperativos de uma verdadeira Reforma”.

\section{O movimento dos sargentos}

Panfleto mantinha uma coluna intitulada "Trincheira dos Sargentos", assinada por Paulo Lemos. Para ele, a luta da categoria naquele momento ocorria em duas frentes. A primeira era pela anistia política aos sargentos que participaram da rebelião em Brasília em setembro de 1963. A segunda era pelo direito de elegibilidade. Ambas as lutas estavam interligadas.

$\mathrm{Na}$ edição de 24 de fevereiro, Paulo Lemos garantiu que a rebelião dos sargentos em Brasília fora em protesto contra a "discriminação odiosa de que foram vítimas. Levantaram-se em defesa de um direito democrático. O direito de serem elegíveis". ${ }^{5}$ Segundo seu argumento, todos são elegíveis, inclusive os oficiais militares, mas não os sargentos, soldados e marinheiros: "Que bela Democracia, uma Democracia hierárquica. Uma Democracia de castas e privilégios. Uma Democracia de força”, afirmou. Muitos sargentos que haviam sido eleitos tiveram seus mandatos cassados pelo Poder Judiciário. "Ficou evidente", alegou, "que temos aí uma justiça de classes, onde os verdadeiros filhos do povo" tiveram seus direitos negados. E o que é ser sargento?

Ser sargento é ser cidadão, chefe de família, filho e pai (...). Ser sargento é colocar acima de tudo o interesse da Pátria 
(...). Ser sargento é sentir com o povo, que precisamos urgentemente de soluções. Reformas radicais, instituição de uma nova ordem social, onde o analfabeto possa participar do processo democrático, onde todos possam trabalhar decentemente e viver como seres humanos (...). Onde o camponês explorado e famélico do interior possa possuir um pedaço de terra (...). Ser sargento é ser amigo de cabos, soldados e marinheiros, irmanar-se com eles na luta de libertação do nosso povo e de nossa Pátria, não mais permitindo a exploração a que estamos sendo submetidos pelos trustes internacionais. (...) Ser sargento acima de tudo é ser povo.

O movimento que ocorreu em Brasília em setembro de 1963 foi, segundo Paulo Lemos, uma luta pacífica pelo direito à elegibilidade. Naquele momento, o Congresso Nacional estava avaliando o projeto de anistia aos sargentos que participaram da rebelião. Desse modo, afirmou Lemos, os parlamentares deveriam resolver as duas reivindicações imediatamente: anistia e direito de elegibilidade. Contudo, se o projeto de anistia fosse rejeitado, concluiu: "nós não seremos responsáveis pelas revoltas que explodirem dentro das bases, quartéis e navios."

$\mathrm{Na}$ edição do dia 23 de março de 1964, Panfleto publicou discurso do tenente José Wilson da Silva, vereador de Porto Alegre, eleito com os votos dos sargentos e suboficiais do Exército, da Aeronáutica e da Brigada Militar: "Não podemos mais admitir este roubo oficializado do qual somos vítimas por parte dos trustes internacionais.” Para acabar com esse processo, era necessária, inicialmente, "pressão sobre o Congresso Nacional, que é pago pelo povo, e NÃO TRABALHA". Segundo o tenente, "faremos com que as cúpulas dirigentes e dominantes, mesmo contra sua vontade, recuem na intenção declarada ou disfarçada de manter seus privilégios, cedendo lugar aos direitos das massas populares". Nesse sentido, ele argumentou:

É preciso que o povo esteja preparado nessa hora em que a burguesia capitalista decreta sua falência, para dar caça às 
velhas raposas que certamente tentarão a fuga, responsabilizando-os perante a justiça do povo, pelos crimes cometidos; devemos nessa hora também, estar preparados, conscientes e politizados, para assumir o poder político na Nação, fazendo com que esse poder seja exercido realmente em nome do povo, atendendo objetivamente o interesse desta grande Nação. (...) Estaremos ao lado do povo e dos seus líderes, pondonos [sic], como POVO FARDADO, com NOSSOS INSTRUMENTOS DE TRABALHO

Para o tenente, a luta seria árdua, mas os sargentos eram "filhos e irmãos de operários e camponeses", enquanto seus filhos eram estudantes. A integração entre eles era irreversível, garantiu.

\section{Miguel Arraes, a Frente Parlamentar Nacionalista, os socialistas e os católicos de esquerda}

Outras lideranças de esquerda também apareciam nas páginas do Panfleto. Esse era o caso do governador de Pernambuco, Miguel Arraes. Em entrevista, ele afirmou que governar não era apenas gerir a máquina administrativa, mas tratava-se, sobretudo, de um ato político. Como exemplo, citou sua iniciativa de exigir o cumprimento das leis no campo, garantindo o direito de organização dos trabalhadores rurais, parceiros e pequenos proprietários em seus sindicatos e cooperativas. Os resultados mais imediatos foram melhorias salariais, maiores vendas no comércio e aumento da produção canavieira, evitando, ainda, o desemprego nas cidades.

Além de aumentar o grau de conscientização e de organização
necessárias à conquista dos nossos objetivos superiores, sem
as quais não poderemos solucionar os problemas brasileiros,
notadamente a liquidação dos monopólios internacionais.

Miguel Arraes também se mostrava favorável à alteração do capítulo da Constituição que tratava das inelegibilidades. Qualquer 
reforma, defendeu o governador de Pernambuco, deveria ser ampla, beneficiando os analfabetos, cabos, sargentos, o ex-presidente Jânio Quadros, o deputado Leonel Brizola e o próprio presidente João Goulart. ${ }^{8}$

A Frente Parlamentar Nacionalista era representada no Panfleto por seu presidente, o deputado federal Sérgio Magalhães. Defendendo o nacionalismo como projeto para a emancipação do Brasil, ele afirmou que a "unidade das forças populares e progressistas é imanente ao processo de libertação nacional" e que a Frente de Mobilização Popular expressava essa unidade. ' Séculos de exploração internacional geraram a miséria no campo e nas cidades, mas fundamentaram a união do povo em torno de suas organizações políticas e da FMP. Os "representantes autênticos das forças populares" estavam unidos em torno de alguns pontos:

(...) fortalecimento das empresas estatais de caráter nacionalista, como a Petrobras, a Eletrobras, a Companhia Siderúrgica Nacional, a Vale do Rio Doce ou a Hidrelétrica do São Francisco. Ou a necessidade do estabelecimento do monopólio estatal do câmbio. Ou a urgência da reforma agrária com a modificação do dispositivo constitucional que impede o pagamento das desapropriações a prazo e em títulos. Ou a urgência da reforma bancária que considere o caráter social do crédito e a nacionalização total da rede de estabelecimentos de crédito. Ou a aplicação rigorosa da lei que limita as remessas de lucros.

Segundo Sérgio Magalhães, essa plataforma unia as forças populares, mas dividia a sociedade brasileira entre os que lutam pela libertação do povo e os que querem manter seus privilégios. O que ocorria no Brasil naqueles dias era um processo de emancipação econômica que avançava com a politização do povo. Os que tentavam dividir essas forças não compreendiam "a existência desse processo de libertação nacional. São reacionários”.

Max da Costa Santos representava a ala esquerda do Partido Socialista Brasileiro na FMP. Um dos personagens mais atuantes na 
Frente, ele afirmou que os dois maiores inimigos do povo brasileiro eram o latifúndio e o imperialismo. Os latifundiários eram representados "fundamentalmente pelo PSD, esse PSD de eterna presença nos postos principais de todos os governos, do atual governo, inclusive". ${ }^{10}$ Mas o imperialismo, tinha vários representantes. Lacerda era o agente mais ostensivo. Nesse sentido, Max da Costa Santos concluiu que "a hora da conciliação já passou". Para ele, "insistir na conciliação é fugir à luta, é enfraquecer o ânimo do povo”. Criticando o presidente, finalizou: “as forças populares estão unidas. Jango é quem diz que não”. Escrevendo regularmente no Panfleto, Santos denunciava a exploração imperialista com a atuação das multinacionais.

Panfleto tinha uma coluna intitulada "Evangelho. Ontem, Hoje e Amanhã”, do padre Aloísio Guerra. Segundo o padre, não adiantava pregar contra o comunismo sem buscar soluções para os problemas do povo. Era o caso do cardeal do Rio de Janeiro em sua mensagem de final de ano. Em vez de levar uma palavra de esperança aos trabalhadores, "tão injustiçados e massacrados quanto escravizados", ${ }^{11}$ apenas desejou que o ano de 1964 tivesse menos comunismo. Para o padre, "tantos crimes contra um povo que sofre crucificado de várias formas e a preocupação é esta?!” A democracia, com o nome de "cristã", é o regime em que o povo é compreendido como "meia-dúzia de nababos", permitindo aos entreguistas "a exploração, o roubo organizado e legalizado". "A "A nossa democracia é ou não de castas?" perguntou. "A democracia e a liberdade pertencem exclusivamente a meia dúzia de nababos. $E$ isto é ou não uma forma disfarçada de totalitarismo?"13

\section{Brizola e o nacionalismo revolucionário}

Com imenso prestígio entre as esquerdas, Brizola expressava e unificava ideias e crenças de organizações e partidos reunidos na FMP. Interpretando a experiência trabalhista no Brasil no contexto 
da guerra fria, da Revolução Cubana, da Guerra do Vietnã e dos movimentos anti-imperialistas latino-americanos, Brizola radicalizou o nacionalismo de matriz getulista.

Em sua leitura da Carta Testamento de Vargas, por exemplo, Brizola afirmou que, naquele texto, encontrava-se a denúncia do quanto era "injusta e desumana" a estrutura econômica e social brasileira. "Todo este quadro de sofrimentos, de necessidades, de misérias e injustiças, nada mais é senão o trágico painel dos efeitos e consequências da espoliação econômica". ${ }^{14}$ Somente com a libertação da "espoliação internacional", o Brasil alcançaria o desenvolvimento econômico e a justiça social. A situação de dependência do país tinha um agravante: as alianças que uma "minoria de poderosos e privilegiados" brasileiros mantinha com os "interesses espoliativos estrangeiros". Tendo como matriz o nacionalismo getulista e o projeto trabalhista, Brizola formulou um conjunto de ideias de esquerda, marcadas sobretudo pelo anti-imperialismo.

O texto acima tinha o título de "A Carta de Vargas" e foi publicado na forma de editorial no primeiro número do Panfleto. A partir daí, todas as edições do Panfleto começavam com editorial escrito por Brizola. Alguns criticavam duramente João Goulart, sobretudo o que as esquerdas definiam como "política de conciliação”. Em um deles, Brizola afirmou que, logo ao tomar posse na presidência, Jango começara a "política de acomodação", aceitando o parlamentarismo. ${ }^{15}$ Mas como dera mostras de que desejava retornar ao sistema presidencialista, manteve-se a aliança entre o governo e o povo. A unidade resultou no plebiscito que devolveu a Goulart os poderes presidencialistas. Na interpretação de Brizola, a imensa vitória obtida pelo governo demonstrou que a vontade popular pelo retorno ao presidencialismo "teve o sentido de um repúdio à política de acomodação, de vacilações, de indefinições, vigorante no período do parlamentarismo".

Embora o povo esperasse que Jango, com seus poderes restaurados, iniciasse uma política "popular, firme e definida", comentou Brizola, o presidente continuou insistindo na "política conciliatória". 
Como resultado, não defendeu os interesses nacionais, impedindo a espoliação internacional e o "saque internacional", não deteve o crescimento da inflação e, mais grave, enfraqueceu a unidade entre povo e governo.

Enquanto o governo procurava a conciliação, o ganha-tempo, os intermináveis entendimentos com os nossos espoliadores, seus sócios e aliados internos haveriam de fortalecer-se. (...) Isto para não falar no quanto desnorteou e dividiu as forças populares, com as quais o governo, até pouco tempo, formava uma unidade invencível, sempre que acionada e dirigida para os caminhos de nossa liberação econômica e social.

Segundo Brizola, os caminhos que resultaram na posse de Jango em setembro de 1961 e na vitória do plebiscito em janeiro de 1963 deveriam ser retomados em vez da "conciliação". Brizola referia-se a dois momentos da história recente do país: a Campanha da Legalidade que garantiu a posse de Goulart e o plebiscito que the devolveu os poderes presidenciais. Em sua interpretação, os dois episódios resultaram em vitórias das "forças populares" contra as direitas devido à união do governo com o povo. Tratava-se de uma crença fortemente disseminada entre as esquerdas: quando o governo buscava o apoio do povo, como em 1961 e 1963, era vitorioso. Jango, desse modo, poderia realizar as reformas de base se tivesse o apoio do povo e das "forças populares".

A maneira de interpretar os acontecimentos da Campanha da Legalidade e da vitória do plebiscito fortalecia, entre as esquerdas reunidas na FMP, a crença de que era possível obter outra vitória em 1964. Brizola, em seus editoriais, garantia que os sucessos anteriores poderiam ser novamente alcançados. Nas duas situações, a sociedade brasileira acompanhou os chamados dos líderes de esquerda. Portanto, era possível mobilizar outra vez o povo pela aprovação das reformas de base e pela instauração de um governo popular e nacionalista, como ocorrera anteriormente. 


\section{Jango e a "política conciliação"}

Para os líderes e militantes da Frente de Mobilização Popular, a maior crítica ao presidente João Goulart era em relação a sua "política de conciliação". A expressão era usada em sentido muito negativo. Mas em uma conjuntura de grande radicalização política, o que significava "conciliação" para as esquerdas reunidas na FMP?

Goulart havia chegado à presidência da República com o país dividido e em gravíssima crise militar e política (FERREIRA 2003 e 2004; GOMES E FERREIRA, 2007). Sua estratégia de governo foi desarmar seus opositores da direita civil e militar, esforçando-se para ampliar sua base política no Congresso Nacional com o apoio do centro, sobretudo do PSD. Seu objetivo era reforçar a aliança entre pessedistas e trabalhistas. De acordo com seus planos, as reformas de base, sobretudo a reforma agrária, seriam negociadas e pactuadas entre os dois partidos. A estratégia de Jango era dar continuidade à aliança partidária que garantira a estabilidade política ao governo de Juscelino Kubitschek e aprovar as reformas. Em sua percepção, o PSD, apesar de seu perfil conservador, não era um partido reacionário, e diversos líderes pessedistas, como JK e Tancredo Neves, estavam dispostos a discutir a reforma a agrária, desde que realizada com moderação. A direita golpista se expressava pela ala de extrema-direita da UDN, liderada por Carlos Lacerda. Jango queria manter suas bases de apoio à esquerda, mas almejava aprovar as reformas por meio de acordos, pactos e compromissos entre o PTB e o PSD.

Para as esquerdas organizadas na Frente de Mobilização Popular, a estratégia presidencial era recusada: acordos com os pessedistas não passavam de "política de conciliação". Sindicalistas, líderes estudantis, sargentos e líderes nacionalistas passaram a exigir do presidente o fim da "política de conciliação" com o PSD. Conciliação tornou-se o termo mais ofensivo entre as esquerdas naquele momento. 
Afinal, se o confronto com as direitas resultaria na vitória das forças reformistas, por que a insistência do presidente em "conciliar" com os pessedistas?

O PSD era interpretado pelas esquerdas reunidas na FMP como partido reacionário e qualquer proximidade com ele era recusada. $\mathrm{Na}$ edição de 9 de março de 1964, uma reportagem tratou da decisão tomada pelo Diretório Regional do PTB no Rio Grande do Sul de vetar o apoio à candidatura de JK à presidência da República em 1965, bem como de repudiar alianças com o PSD. A moção do Diretório Regional, ligado politicamente a Brizola, foi votada com a presença e o apoio da bancada de deputados estaduais e a maioria dos parlamentares federais trabalhistas gaúchos, além de diversos dirigentes municipais. A decisão foi tomada recorrendo aos seguintes argumentos:

1 - Pelo que o PSD representa de reacionarismo e antirreforma no País; 2 - Pelas suas origens e vinculações com as velhas oligarquias, cuja ação política só visa a defender odiosos privilégios antipopulares. ${ }^{16}$

João Caruso, presidente do PTB gaúcho, perguntou o que significava a candidatura de JK. Para ele, tratava-se da

perpetuação da iniquidade. O predomínio das mesmas forças que agora nos agridem e nos oprimem. A permanência das mesmas classes dirigentes (...). A subserviência aos nossos espoliadores. (...) Significaria que renegamos a nossa fé, repudiamos o nosso passado, rasgamos a bandeira das reivindicações populares, de que nos fizemos portadores.

Alianças com o PSD eram descartadas pelas esquerdas unidas no FMP. Na edição do Panfleto de 23 de março de 1964, uma nota fazia referência à Convenção realizada pelos pessedistas. Com seu "apetite de poder" e o "apoio dos latifundiários", além da "mais radical inconsistência ideológica”, o PSD aclamou JK como candidato à 
presidência nas eleições de $1965 .{ }^{17}$ Os ataques a Juscelino aumentaram com a confirmação de sua o candidatura. Na edição de 30 de março de 1964, uma reportagem desqualificava seu governo. Com o título de "Juscelino, candidato da Hanna", o texto afirmava que JK insistia na questão do desenvolvimento econômico.

Mas até agora (...) não contou aos brasileiros por que o seu plano de metas, no que respeita à exportação de minério de ferro, foi todo ele elaborado por homens que ao mesmo tempo eram assalariados da Hanna Corporation e em seus pareceres defenderam sempre a participação dos grupos internacionais e da empresa norte-americana na nossa exportação de minérios contra a independência econômica do Brasil. ${ }^{18}$

As esquerdas reunidas na FMP recusavam qualquer aproximação com o PSD. Cobravam de Jango seu rompimento com aquele partido e a formação de um governo nacionalista e popular, apoiado exclusivamente nas forças políticas reunidas na FMP.

\section{A Constituição e as reformas}

Desde o início do governo Goulart, as esquerdas criticavam alguns dispositivos constitucionais que impediam a efetivação das reformas. Dois deles eram recorrentes. O primeiro era o parágrafo 16 do artigo 141, que estabelecia o seguinte: "É garantido o direito de propriedade, salvo o caso de desapropriação por necessidade ou utilidade pública, ou por interesse social, mediante prévia e justa indenização em dinheiro." O artigo 147 completava e reforçava o artigo 141. Sem dúvida, esses artigos impediam a implementação da reforma agrária. Da maneira como estavam redigidos, as desapropriações eram do interesse do proprietário. Para as esquerdas, a reforma agrária não poderia implicar indenização alguma. Outro dispositivo constitucional interpretado como excludente era o que se 
referia ao direito de votar e ser votado. A Constituição excluía do alistamento eleitoral os analfabetos, os praças, os suboficiais e os sargentos das Forças Armadas. Os parentes consanguíneos e afins do presidente e do vice-presidente da República eram inelegíveis para cargos no Poder Executivo e alguns no Poder Legislativo.

Para o PTB, a lei das elegibilidades era prejudicial aos seus interesses eleitorais naquele momento. Enquanto a UDN dispunha de dois nomes de grande competitividade - Carlos Lacerda e Magalhães Pinto - e o PSD já lançara a candidatura de Juscelino Kubitschek, o PTB não tinha um nome de peso. Seus maiores líderes estavam impedidos de participar das eleições: João Goulart não podia se reeleger e Leonel Brizola, cunhado de Jango, não podia concorrer.

As esquerdas reunidas na FMP passaram a exigir do Congresso Nacional uma reforma constitucional. Em editorial no Panfleto, o secretário-geral da FMP, Neiva Moreira, pediu urgência para uma reforma eleitoral que resultasse na "verdadeira democratização do voto e do sistema representativo". ${ }^{19}$ Contudo, afirmou: setores do Congresso Nacional têm impedido o "voto livre e autêntico", receosos de que a democratização eleitoral signifique "sua liquidação política”. Pequenas cúpulas partidárias indicavam candidatos e a Nação homologava as decisões dessa minoria.

Eleição hoje, sem voto de analfabeto, com a ingerência escancarada e decisiva do poder econômico, com tantas inelegibilidades que no final privam o eleitor de votar em quem deseja, pode ser tudo menos uma escolha democrática e livre da verdadeira representação do povo.

Por essa razão, continuou Neiva Moreira, os grupos dirigentes vivem receosos em relação a "soluções revolucionárias". Para ele, "ninguém inventa revolução, do mesmo modo que não tem como impedi-la se as condições estão criadas”. Assim, as eleições de 1965 poderiam gerar algo similar ao que ocorreu em 1930: o conflito entre "o povo marginalizado e o sistema antidemocrático". 
Nas páginas do Panfleto, o questionamento das instituições liberal-democráticas da Constituição de 1946 era comum. No editorial da edição de 9 de março de 1964, lia-se: "Valendo-se de um sistema eleitoral falho, que não reflete a vontade popular, a direita conquistou o governo de alguns estados fundamentais - Guanabara, São Paulo e Rio Grande do Sul." ${ }^{\prime 20} \mathrm{Na}$ mesma página, Maio Neto, criticando a falta de construção de habitações populares no país, afirmou que o problema ocorria porque "uma liberal-democracia, como a nossa, mais preocupada com os aspectos formais do que com os de essência, registra, em sua Constituição, largas páginas dedicadas aos direitos do homem". Mas, segundo seu argumento,

é estranho, também, que, sendo tão minuciosa, no que se refere aos direitos abstratos - como liberdade de palavra, inviolabilidade individual e outros - a nossa lei básica não tivesse acrescentado, à sua relação de direitos e garantias, outros que mais e mais se fazem indispensáveis a este povo: o direito de comer, por exemplo. ${ }^{21}$

Na edição de 16 de março do Panfleto foi publicada a propaganda de um dos volumes da série Cadernos do Povo Brasileiro. $\mathrm{O}$ texto explicativo sobre o livro dizia:

Finalmente ao alcance do povo o livro que abalará a Nação brasileira! Que é a Constituição? de Osny Duarte Pereira. Que interesses determinaram a redação de seus artigos? Quais os constituintes que se prestaram ao resguardo desses interesses antinacionais? Que privilégios imorais são por ela consagrados? Que é a Constituição? (Cadernos do Povo Brasileiro, n. 23) demonstra insofismavelmente que o povo tem razão quando reclama a reforma constitucional. ${ }^{22}$

Entrevistas, artigos e editoriais publicados no Panfleto exigiam mudanças na Constituição, enquanto as instituições da democracia liberal eram questionadas. Para Daniel Aarão Reis, as esquerdas 
durante o governo Goulart adquiriram um perfil reformista revolucionário. Trata-se de um movimento comprometido com reformas, mas as suas realizações implicavam rupturas revolucionárias. Nos primeiros meses de 1964, afirma o autor,

configurava-se uma clara ofensiva política reformista-revolucionária dos movimentos mais radicalizados. Crescia a descrença na possibilidade de que as reformas pudessem ser conquistadas nas margens legais (AARÃO REIS, 2004, p. 35).

\section{As duas Frentes e a escolha do presidente}

Em fins de 1963 e início de 1964, a radicalização alcançou níveis muito preocupantes para a estabilidade política do país. As esquerdas, agrupadas na FMP e lideradas por Leonel Brizola, atacavam duramente João Goulart. As direitas, por sua vez, avançavam no processo conspiratório. A intransigência do governo dos Estados Unidos de não renegociar a dívida externa levava o país à falência. O objetivo era estrangular financeiramente o Brasil, desgastando o governo. No contexto da guerra fria, o avanço das esquerdas assustava os setores conservadores e direitistas.

Jango não obteve sucesso em sua política de unir o centro pessedista com a esquerda trabalhista e, com maioria no Congresso, viabilizar as reformas. A ala radical dos trabalhistas e as esquerdas organizadas na FMP recusavam negociações com os pessedistas, apostando na política do confronto. O PSD, temeroso com o processo de radicalização, aproximava-se da UDN. Todas as iniciativas de Goulart para manter a coligação trabalhista-pessedista resultaram em fracasso.

No entanto, alternativas à crescente radicalização existiam e Jango poderia dispor delas. Em janeiro de 1964, Santiago Dantas, liderando políticos do PTB e de outros partidos, propôs a formação 
da Frente Progressista de Apoio às Reformas de Base (FIGUEIREDO, 1993 e GOMES, 1994). Dantas estava preocupado com o isolamento político do governo, com a oposição agressiva das esquerdas, a hostilidade crescente do PSD e o avanço da conspiração das direitas. Com o processo de radicalização, ele acreditava que nem as reformas seriam implementadas nem o regime democrático teria continuidade. A Frente Progressista, qualificada pelo próprio Dantas de "esquerda positiva", para diferenciá-la da "esquerda negativa", referindo-se à Frente de Mobilização Popular, teria como objetivo impedir o crescimento da conspiração das direitas, reagrupando as forças de centro-esquerda no sentido de apoiar o governo. Os objetivos da Frente eram retirar o presidente do isolamento político, sustar o processo de radicalização das direitas e das esquerdas e aprovar as reformas de base. Na formação da Frente Progressista, Dantas buscou o apoio do PSD, do PCB e do PTB que não seguia a liderança de Brizola. Também queria o apoio de Miguel Arraes e de sindicalistas não alinhados com o CGT (FIGUEIREDO, 1993, p. 143-144). Nesse momento, havia duas frentes políticas que disputavam o apoio de Goulart. Na avaliação de Angela de Castro Gomes, ambas "pressionavam Jango, uma lutando pela legalidade e outra por sua ruptura" (GOMES, 1994, p. 160).

Santiago Dantas e sua Frente Progressista tornaram-se, desse modo, os concorrentes mais imediatos de Leonel Brizola e da FMP. Ambos passaram a disputar o apoio político de Goulart. Não casualmente, Carlos Lacerda e Santiago Dantas tornaram-se os personagens mais atacados no Panfleto. O primeiro era o líder da extrema-direita; o segundo, o líder da esquerda moderada.

No primeiro número do Panfleto, liam-se graves denúncias contra Santiago Dantas. Longa reportagem o acusava de causar prejuízos de bilhões de cruzeiros para os cofres públicos, beneficiando os Estados Unidos. A acusação era de que, no Ministério da Fazenda, "foi apanhado em flagrante negociata - a compra da Bond and Share". ${ }^{23}$ Para o editorialista, com tantas denúncias, não era possível levar a sério sua proposta de formação de uma Frente e 
juntar num mesmo esquema político o que de mais autêntico apresenta o quadro brasi-leiro - Brizola, Arraes, CGT, UNE, CGTI, Organizações Camponesas, Sargentos e Oficiais Nacionalistas, comunistas brasileiros, Frente Parlamentar Nacionalista, Frente de Mobilização Popular - com as velhas raposas do PSD. Maior se torna o absurdo dessa "coligação", quando conhecido o seu objetivo: a realização das reformas.

Nesse sentido, concluiu o editorial, Goulart teria que fazer sua opção. Se escolhesse a FMP,

o apoio das forças populares será total, incondicional, não terá preço e se manifestará por todas as maneiras, em praças públicas e de armas nas mãos, se necessário. O que não faz sentido é que o Presidente João Goulart, com livre acesso às áreas populares, escolha tal intermediário.

As esquerdas reunidas na Frente de Mobilização Popular recusaram, de maneira categórica, a proposta de Santiago Dantas, negando-se a aceitar qualquer acordo com o PSD. Na análise de Neiva Moreira, o PSD vivia de privilégios e se mantinha artificialmente no poder devido a um "sistema eleitoral antidemocrático, que exclui das decisões imensos setores do povo". ${ }^{24}$ Segundo seu argumento:

as forças populares são a maioria do país [...] e pelo seu vigor e a vitalidade de suas ideias, reivindicam a liderança do poder, para a execução de seu programa. [...] Um programa popular e nacionalista executado por um governo homogêneo, afinado com a audácia das grandes decisões só pode partir de uma base doutrinária coerente.

Neiva Moreira descartava a proposta de Santiago Dantas e da Frente Progressista, qualificada por ele como um mero rótulo para garantir o domínio do PSD no governo Jango. A fórmula tinha por objetivo "neutralizar o governo" e "anestesiar o povo", abrindo 
caminho para um novo período de "dominação das forças mais retrógradas e intolerantes do país”.

No início de 1964, Goulart fez sua escolha. Preferiu ter como base de apoio político a FMP e sua estratégia ofensiva. Descartou a alternativa moderada de Santiago Dantas. Não se sabe por que ele escolheu a alternativa da radicalização, tratando-se de um político que sempre preferiu a negociação e o acordo. Possivelmente, a escolha pela Frente Progressista de Dantas o afastaria de suas bases sindicais e de esquerda, tornando-o refém político do PSD. Em fins de janeiro de 1964, Jango aceitou a proposta de realização de um comício na Central do Brasil, marcado para 13 de março, aderindo ao programa da Frente de Mobilização Popular e selando sua aliança política com as esquerdas que a integravam. No evento, ele anunciaria uma série de reformas.

\section{O comício da Central e o governo das esquerdas}

Com a manchete "Povo sepulta a conciliação", Panfleto, na primeira página da edição de 16 de março de 1964, descreveu o comício que ocorrera na Central do Brasil dias antes, em 13 de março. O secretário-geral da FMP, Neiva Moreira, com satisfação, afirmou que, "na praça pública, foi sepultada a política de conciliação" 25 e que Jango deveria recompor todo o seu governo:

O próximo passo será varrer a máquina política da espúria infiltração, barrar os caminhos do imperialismo e consolidar as conquistas da revolução, através de um poder doutrinariamente coerente e funcionalmente coerente e integrado.

Referindo-se a um processo revolucionário em curso, o secretário-geral da Frente exigia que o presidente fosse coerente com suas decisões no comício, retirando os homens do PSD de seu 
governo, passando a compor, unicamente, com os partidos e organizações da FMP.

No palanque, falaram as principais lideranças das organizações que compunham a Frente de Mobilização Popular. Um dos oradores mais esperados era Leonel Brizola. Discursando em nome da FMP, ele retomou o argumento que defendia no Panfleto: a necessidade da união entre povo e governo. Brizola afirmou que essa unidade existiu em 1961, "quando o povo, praticamente de fuzil na mão, repeliu o golpismo", mas também no plebiscito de 1963, quando mais de dez milhões de eleitores "exigiram o fim da conciliação do parlamentarismo" e a realização das reformas. ${ }^{26}$ Para Brizola,

se conseguirmos hoje a restauração daquela unidade, o presidente poderá retornar, através da manifestação do povo, às origens de seu governo. E, para isso, será suficiente que ponha fim à política de conciliação e organize um governo realmente democrático, popular e nacionalista.

Segundo seu argumento, o país chegara a um impasse:

Não podemos continuar nessa situação. O povo está a exigir uma saída. Mas o povo olha para um dos poderes da República, que é o Congresso Nacional, e ele diz NÃO porque é um poder controlado por uma maioria de latifundiários, reacionários, privilegiados e de ibadianos. É um Congresso que não dará mais nada ao povo brasileiro. $\mathrm{O}$ atual Congresso não mais se identifica com as aspirações de nosso povo. A verdade é que, como está, a situação não pode continuar. (...) E o Executivo? Os poderes da República, até agora, com suas perplexidades, sua inoperância e seus antagonismos, não decidem.

A alternativa defendida para a superação do impasse entre o povo e os poderes da República era, desde fins de 1963, discutida pelas forças políticas que integravam a Frente de Mobilização Popular. Brizola apresentou a proposta: 
Por que não conferir a decisão ao povo brasileiro? $O$ povo é a fonte de todo o poder. Portanto, a única saída pacífica é fazer com que a decisão volte ao povo através de uma Constituinte, com a eleição de um congresso popular, de que participem os trabalhadores, os camponeses, os sargentos e oficiais nacionalistas, homens públicos autênticos, e do qual sejam eliminadas as velhas raposas tradicionais.

Pelo programa defendido pela FMP, uma Assembleia Nacional Constituinte substituiria o Congresso Nacional e, ao mesmo tempo em que redigiria uma nova Constituição, aprovaria as reformas de base. Formada por trabalhadores urbanos e rurais, junto com sargentos e oficiais nacionalistas das Forças Armadas, eleitos sem a influência do poder econômico e da imprensa reacionária, a Constituinte expressaria a vontade do povo - e não das classes dominantes. Continuando, Brizola afirmou:

Dirão que isto é ilegal. Dirão que isto é subversivo. Dirão que isto é inconstitucional. Por que, então, não resolvem a dúvida através de um plebiscito? Verão que o povo votará pela derrogação do atual Congresso.

Ao término de seu discurso garantiu: "o nosso caminho é pacífico, mas saberemos responder à violência com a violência". E desafiando o presidente, finalizou: "O nosso presidente que se decida a caminhar conosco e terá o povo ao seu lado. Quem tem o povo ao seu lado nada tem a temer".

O comício na Central do Brasil foi o primeiro de uma série planejada entre as esquerdas reunidas na FMP e o presidente. Novos comícios foram programados para abril: dia 3, em Santos; 10, em Santo André; 11, em Salvador; 17, em Ribeirão Preto; 19, homenageando Vargas, em Belo Horizonte; 21, em Brasília. O último, marcado não casualmente para $1^{\circ}$ de maio, seria realizado na capital paulista, deflagrando uma greve geral. A estratégia era pressionar o Congresso Nacional, incitando a população contra ele nas ruas. 
Com o parlamento fragilizado pela pressão do povo, as esquerdas acreditavam que encontrariam forças para alterar a Constituição e aprovar as reformas de base. O programa mais imediato das organizações sob a liderança de Brizola era a realização de um plebiscito sobre a necessidade de convocar uma Assembleia Nacional Constituinte.

No editorial intitulado "Constituinte sem golpe", do Panfleto de 16 de março, ${ }^{27}$ o editorialista argumentava que o comício da Central do Brasil demonstrara, com clareza, o impasse vivido pela Nação brasileira: "o desencontro entre a realidade dinâmica e a estrutura de instituições envelhecidas ou totalmente superadas". Com as contradições sociais exacerbadas, o crescente processo inflacionário e as vacilações do governo, "todos sentem que vivemos uma véspera". $\mathrm{O}$ editorial continuava com críticas ao presidente João Goulart e ao Congresso Nacional:

Preso a um esquema de conciliação, mobilizando tudo, desde a habilidade política até a 'fisiologia' mais desenfreada, o Presidente da República não quis entender que é impossível conciliar um PSD decadente e esclerosado com as impetuosas forças de vanguarda que surgem no cenário do país. Por seu lado, o Congresso é o grande mudo, enrolado no varejo da pequena legislação ou fazendo o jogo das aparências e farisaísmo que nada têm de comum com as angústias do povo.

O editorialista denunciou que a solução para as minorias privilegiadas da sociedade brasileira, com apoio do imperialismo, era o golpe de Estado. As "forças populares", no entanto, impediriam. Mas ser contra golpes não significava apoiar um "Executivo amarrado", um "Congresso inativo" e um "Judiciário às filigranas de leis confusas ou interpretadas sempre contra o povo”. O Brasil chegara a um impasse e o problema somente seria solucionado com uma consulta popular sobre a necessidade de convocação de uma Assembleia Constituinte. Somente com uma Constituinte, "eleita 
com a participação das forças renovadoras que compõem o novo poder em nosso país, será possível sair da crise e abrir caminho à emancipação econômica nacional". Uma das reivindicações mais imediatas era a extensão do direito do voto aos analfabetos, praças e sargentos, bem como permitir a elegibilidade daqueles que, pela legislação em vigor, não podiam concorrer a cargos executivos como Leonel Brizola. Desse modo, seria possível "abrir à Nação uma perspectiva de saída pacífica para a crise”. Concluindo, o editorialista afirmou: "Constituinte para evitar o golpe. Plebiscito pra abrir caminho à revolução pacífica".

Nesse momento, amplas parcelas dos empresários nacionais, bem como importantes grupos civis e militares, demonstravam unânime desconfiança em relação ao governo, afirma Maria Celina D’Araújo (1996, p. 154 e 264). No entanto, mesmo com toda a conjuntura desfavorável, Rodrigo Sá Motta considera que a deposição de Goulart da presidência da República não era um processo inexorável. Desde o início de seu governo, os políticos conservadores e moderados deram a ele um voto de confiança, esperando que resolvesse alguns problemas cruciais vividos pelo país, como a crise econômica, o crescimento da inflação e a instabilidade política derivada da radicalização entre direitas e esquerdas. Para o autor, "Goulart gozaria de apoio tranquilo, desde que a esquerda radical fosse afastada do círculo do poder" (MOT'TA, 2002, p. 251-252). O quadro político tornou-se outro após o comício da Central do Brasil. A bibliografia sobre o governo Goulart converge no sentido de interpretar a manifestação de 13 de março como o estabelecimento da aliança política entre o presidente e as esquerdas. Jango, a partir daí, governaria exclusivamente com a FMP e adotaria seu programa político. Para Rodrigo Sá Motta, "no campo conservador, o comício da 'sexta-feira 13 ' foi recebido com alarme". Os conservadores e anticomunistas estavam certos de que o evento resultaria "inexoravelmente num golpe esquerdista com participação ativa dos comunistas". Para o autor, 
setores sociais importantes, que, até então, mantinham-se em expectativa, alguns inclusive simpáticos à pregação reformista, alinharam-se ao lado da direita e dos conservadores, sob a bandeira do anticomunismo (MOTTA, 2002, p. 263264).

\section{A Mensagem do Presidente}

Dois dias após o comício da Central do Brasil, o presidente João Goulart enviou Mensagem ao Congresso Nacional. O texto é pouco conhecido, embora muito importante para o desenrolar da crise política que culminou com o golpe de Estado. Redigido por Darcy Ribeiro, a Mensagem era uma prestação de contas do governo ao Congresso Nacional, mas o capítulo "O caminho brasileiro", em que o presidente solicitava providências aos parlamentares, foi elaborado em comum acordo com as lideranças da Frente de Mobilização Popular e publicado no Panfleto.

O presidente, inicialmente, fez referências ao plebiscito que restituiu seus poderes presidencialistas. ${ }^{28}$ A sociedade brasileira sabia que sua plataforma política eram as reformas de base. Assim, ele convocou o Congresso Nacional para a "adoção de uma reforma constitucional".

A mais importante reforma era a da estrutura agrária. Pela proposta presidencial, ficaria estabelecido que "a ninguém é lícito manter a terra improdutiva por força do direito de propriedade". Mas o que viabilizaria a reforma agrária eram as alterações que o presidente propunha nos artigos 141 e 147 da Constituição, modificações reivindicadas pelas esquerdas. Como vimos anteriormente, o parágrafo 16 do artigo 141 estabelecia o seguinte: “É garantido o direito de propriedade, salvo o caso de desapropriação por necessidade ou utilidade pública, ou por interesse social, mediante prévia e justa indenização em dinheiro." $\mathrm{Na}$ Mensagem, Jango propunha suprimir 
do texto a palavra "prévia" e a expressão "em dinheiro". Tratava-se, na verdade, da mais importante reivindicação das esquerdas: reforma agrária sem indenização prévia em dinheiro.

Goulart também propunha outra alteração da Constituição: a que tratava da reforma eleitoral. Jango alegava que a "Constituição de 1946, entre outros privilégios, consagrou, no campo eleitoral, normas discriminatórias". Era o caso dos praças e sargentos e dos analfabetos, impedidos de votar. Também eram inelegíveis parentes consanguíneos e afins, até o segundo grau, de personalidades que exercessem cargos no Poder Executivo e alguns no Poder Legislativo - dispositivo que impedia Leonel Brizola, cunhado de Jango, de concorrer nas eleições presidenciais de 1965. Assim, pela proposta contida na Mensagem, seriam alistáveis para exercer o direito do voto todos os brasileiros que soubessem se expressar em língua nacional, excetuando os casos incorridos no artigo 135 da Constituição - incapacidade civil e condenados por crimes. Também seria acrescentada a expressão: "São elegíveis os alistáveis." Com a nova redação do texto constitucional, os praças, os sargentos e os analfabetos teriam o direito ao voto, enquanto Leonel Brizola poderia concorrer à sucessão de Jango na presidência. Outra consequência da proposta era que, na prática, estaria instituída a reeleição no Poder Executivo, beneficiando o próprio Goulart.

O presidente também propunha a reforma do ensino superior, extinguindo a "cátedra" e sua vitaliciedade. Além disso, a Mensagem tratava das relações entre Executivo e Legislativo: “o cumprimento dos deveres do Estado moderno não se concilia com uma ação legislativa morosa e tarda". A sugestão era "suprimir o princípio da indelegabilidade dos poderes, cuja presença no texto constitucional só se deve aos arroubos de fidelidade dos ilustres constituintes de 1946 a preceitos liberais do século XVIII". Jango propunha revogar o parágrafo $2^{\circ}$ do artigo 36 da Constituição, que dizia: “É vedado a qualquer dos Poderes delegar atribuições.” Na prática, o Executivo poderia exercer atribuições do Legislativo. Como última medida 
contida na Mensagem, Jango sugeria a convocação de um plebiscito para o povo se pronunciar a respeito das reformas de base.

No Congresso Nacional, a Mensagem foi recebida de maneira negativa entre parlamentares de oposição e os pessedistas. A proposta de reforma agrária não surpreendeu. Os parlamentares sabiam que expropriações sem indenizações faziam parte do programa do presidente e das esquerdas. Mas estas também sabiam que o Congresso recusaria a iniciativa presidencial.

A repercussão mais negativa da Mensagem foi causada por sua parte política, geradora de suspeitas e desconfianças. A extensão do direito de voto aos analfabetos beneficiaria diretamente o PTB, partido muito popular naquele momento. Tudo indicava que os analfabetos, contingente mais pobre da população, votariam nos trabalhistas. No que se refere à sucessão presidencial, a proposta de reforma eleitoral também vinha ao encontro das necessidades políticas do PTB. Enquanto o PSD e a UDN tinham políticos de grande expressão para a eleição de 1965 - Juscelino Kubitschek entre os pessedistas e Carlos Lacerda e Magalhães Pinto entre os udenistas -, os trabalhistas não tinham um candidato de peso. A reforma eleitoral permitiria ao PTB dispor de dois fortes nomes: Brizola e o próprio Jango. Mais surpreendente foi a proposta de delegação de poderes, que assustou diversos setores políticos. Parlamentares no Congresso Nacional se perguntavam: o que Jango queria ao dispor, ao mesmo tempo, de poderes executivos e legislativos? O plebiscito, por sua vez, daria ao presidente uma vitória muito expressiva - pesquisas apontavam a grande popularidade das reformas de base entre a população. Uma votação esmagadora a favor das reformas fragilizaria o Congresso diante do presidente da República.

Grupos civis e militares de direita estavam decididos a golpear as instituições, sobretudo após o comício de 13 de março. Mas com a Mensagem presidencial, as lideranças direitistas ficaram convencidas de que "estava em andamento um plano continuísta acoplado a um projeto de concentração de poderes excepcionais por parte 
do Executivo", no dizer de Maria Celina D’Araújo (1996, p. 157). Também na análise de Carlos Fico, "o presidente dava sinais dúbios de suas verdadeiras intenções, havendo forte suspeita de que ele estaria urdindo um golpe que lhe permitisse um segundo mandato, proibido pela Constituição". Fico ainda lembra que "o líder comunista Luís Carlos Prestes apoiava uma reforma constitucional nesse sentido" (FICO, 2004, p. 17). As medidas propostas na Mensagem alimentaram hipóteses de que um golpe estava sendo planejado por Jango e Brizola. Para os conservadores e partidos de centro, como o PSD, receios e temores surgiram com as propostas de Goulart. Assustados, cederam aos argumentos da direita golpista. A Mensagem presidencial gerou desconfianças generalizadas, beneficiando líderes de direita e grupos de conspiradores civis e militares que necessitavam de aliados para desferir o golpe de Estado. Considerando ainda o anticomunismo, os argumentos que defendiam o combate à corrupção, a busca de estabilidade econômica e a preservação da hierarquia na Forças Armadas, o campo conservador, na avaliação de Gunter Axt, "convergiu e se fortaleceu. Dessa união brotou a insurreição” (AXT, 2008, p. 453).

\section{As esquerdas no poder}

Na última semana de março, o presidente João Goulart sofreu fortes pressões de seus aliados políticos na FMP.

O sexto número do Panfleto chegou às bancas de jornal com data de 23 de março. Naquele momento, Jango tinha a Frente de Mobilização Popular como base de apoio político. A estratégia de pressionar o Congresso Nacional com novos comícios estava mantida, enquanto a Mensagem contemplava as reivindicações mais imediatas das esquerdas. Um novo ministério deveria dar feição ao governo da FMP. O secretário-geral da Frente, Neiva Moreira, alegou que, passada a euforia com o comício de 13 de março, era necessário que Jango formasse um novo ministério. 
O que se impõe é a ação rápida e ofensiva. Ora, o programa da Frente Nacionalista, condensado recentemente em nota da Frente de Mobilização Popul-ar, tem tudo ou quase tudo o que se quer e precisa fazer. É só nomear os ministros do Governo Popular e começar a ofensiva geral em todas as frentes. ${ }^{29}$

Para Neiva Moreira, o programa existia, faltando executá-lo.

$\mathrm{Na}$ mesma edição, o editorial assumiu posição de ofensiva política. "O Brasil está vivendo um clima de Espanha, 1936". A guerra civil estava sendo preparada pelos reacionários. Para o editorialista, "o povo está certo de que vive uma véspera de transcendental importância histórica e se aflige ao ver que o conluio imperialista e reacionário avança (...)". Desse modo, continuou,

quando o povo luta pela revisão constitucional está certo. O fetichismo da ordem jurídica intocável é absurdo. O nosso compromisso é o da democracia verdadeira, que é regime do povo. Uma constituição pode ou não ser popular e, se não for, deixará, necessariamente, de ser democrática. Nessa linha de ação, o plebiscito que defendemos para consultar o povo sobre a Constituição que fará as Reformas pode não ser rigorosamente constitucional, mas é inequivocamente democrático. É, ainda, uma saída contra a guerra civil, que a reação elabora nos subterrâneos do crime político e da traição nacional. Todos os patriotas devem se lançar a essa luta, certos de que, se a democracia é intocável, a Constituição não pode ser uma camisa de força.

Encerrando o texto, o editorialista lançou as palavras de ordem:

O povo quer as Reformas. O Congresso as recusa. Diante do impasse, as palavras de ordem justas para as forças populares devem ser:

$1^{\circ}$ - Manutenção intransigente das liberdades democráticas;

$2^{\circ}$ - Unidade das forças autenticamente populares;

$3^{\circ}$ - Formação de um governo popular nacionalista; 
$4^{\circ}$ - Plebiscito sobre a convocação de uma constituinte;

$5^{\circ}$ - Democratização do voto para a sucessão.

Esta é hora de definição e de luta. O povo deve vigiar e agir. Nossa pátria não dará passos atrás, não será uma nova Espanha ou um Paraguai ampliado. O processo de libertação nacional seguirá seu curso, mesmo à custa de todos os sacrifícios.

As esquerdas reunidas na Frente de Mobilização Popular, naquele momento no poder e base de sustentação política de Goulart, decidiram pelo rompimento com o regime liberal-democrático, inaugurado pela Carta de 1946. Os instrumentos eram o plebiscito e a Constituinte.

\section{A crise militar, a crise final}

Desde a posse de João Goulart até fins de 1963, a conspiração direitista contra ele era, na definição de Rodrigo Sá Motta, "confabulações de grupos radicais à margem do processo político" (MOTTA, 2002, p. 268). Para o autor, foi somente no início de 1964 que a "coalizão conservadora, majoritariamente, inclinou-se pela ruptura institucional". Até aquele momento, a "direita radical, mais especificamente, os anticomunistas extremados, encontrava-se numa posição isolada em relação à opinião conservadora" (MOTTA, 2002, p. 273). Mas em meados de março de 1964, a conspiração formava um amplo leque de alianças, privando Jango do apoio do centro político. Em fins do mesmo mês, as condições para a deposição do presidente estavam postas. "Faltava apenas a fagulha, o elemento para detonar o mecanismo golpista e empurrar à ação os que ainda hesitavam ante a hipótese de rompimento institucional" (MOTTA, 2002, p. 268). O episódio foi a revolta dos marinheiros e fuzileiros navais, cuja Associação integrava a FMP.

Em seu último número, em 30 de março, Panfleto noticiou a rebelião, defendendo os marinheiros. De acordo com as reportagens, 
diversas organizações de esquerda apoiaram ativamente a revolta. Ainda no primeiro dia, durante assembleia dos marinheiros, o vicepresidente do CGT, Dante Pelacani, afirmou que a luta, naquele momento, não mais pertencia "aos marujos, mas a todo o povo, inclusive porque o Exército também é povo. Os gorilas não terão coragem para invadir esta assembleia". ${ }^{30}$ Álvaro Lins, em nome do Comando Geral dos Trabalhadores Intelectuais declarou que a rebelião era um "ato histórico da revolução brasileira, e que a constituição não pode ser usada como um tabu, nem os marinheiros deveriam acatar ordens injustas". Segundo noticiado no Panfleto, o CGT, por meio de Osvaldo Pacheco, Hércules Correa e Dante Pelacani, manteve os operários em estado de alerta, com dispositivos prontos para deflagrar greves. Representando a Frente Parlamentar Nacionalista, o deputado Max da Costa Santos foi quem sugeriu que os marinheiros se concentrassem no Sindicato dos Metalúrgicos. Ainda segundo Panfleto, o CGTI deu assistência completa aos marinheiros, a UNE mobilizou os estudantes e a Liga Feminina Nacionalista levou mantimentos, enquanto os sargentos estavam determinados a não cumprirem ordens consideradas injustas. Leonel Brizola e Miguel Arraes eram informados dos acontecimentos a cada meia hora, mantendo "seus dispositivos de alerta todo o tempo". Segundo Panfleto, a crise começou a ser solucionada quando, logo ao chegar ao Rio de Janeiro, Goulart teve "uma conferência secreta com o deputado Leonel Brizola, com quem examinou a situação".

Em negociação com o CGT, Goulart nomeou o novo ministro da Marinha. Os marinheiros se entregaram ao Exército e foram anistiados pelo governo. Para amplos setores militares e civis, o que estava em curso no país era um processo revolucionário em estágio avançado, sobretudo com a desmoralização da hierarquia e da disciplina nas Forças Armadas. João Goulart e as esquerdas que compunham a Frente de Mobilização Popular não perceberam a gravidade daquele episódio.

O desafio à hierarquia e à disciplina nas Forças Armadas continuou presente nas páginas do Panfleto. Na mesma edição de 
30 de março, Paulo Lemos, na coluna "Trincheira dos Sargentos", escreveu matéria com o seguinte título: "Anistia ou Revolução". ${ }^{11}$ Sua preocupação era com o projeto de anistia aos sargentos que participaram da revolta em Brasília, em setembro de 1963, e que estava para ser votado no Congresso Nacional. O movimento dos sargentos esperava que os parlamentares aprovassem a anistia. $\mathrm{O}$ texto era contundente. De um lado, os sargentos presos; do outro, os deputados e senadores. Segundo Paulo Lemos:

Vós [deputados e senadores] representais o passado, o velho, o obsoleto. Eles [os sargentos] representam o novo, o futuro de um povo, a esperança da pátria. Vós terminais. Eles começam. Eles vencerão. Vós sereis os derrotados. E o tratamento que recebemos agora vos será retribuído em dobro, no alvorecer do novo dia, que não está longe, pois, já vivemos a aurora feliz e radiante deste amanhecer. (...) Vós agonizais. Usais de vossos últimos recursos. Os trabalhadores, os camponeses, os estudantes, os sargentos, cabos, soldados e marinheiros, são o povo e a nós, sobra-nos ainda muita resistência, capaz de enfrentar a luta e vencê-la. Aí a justiça popular será implacável.

Para Paulo Lemos, o povo brasileiro já tinha consciência de seu papel histórico: "os sargentos de fuzil na mão e abraçados ao povo" farão a independência econômica do Brasil, "pacificamente ou não". Era preferível que a libertação fosse por meio pacífico, "mas aceitaremos a luta em qualquer terreno e de qualquer maneira". Quando for preciso, "saberemos usar nossas armas e, entrincheirados ao lado do povo, os sargentos saberão sobre quem apontar a alça de mira". Os deputados e senadores estavam diante dela, afirmou Paulo Lemos, e "somente votando a lei da anistia, a reforma agrária radical, as demais reformas que o país precisa e o povo clama, é que podereis ficar a salvo". Por fim, a ameaça final: "Este é um brado de alerta. Talvez o último. Ao torpedeardes a anistia e as reformas, o que estais fazendo é cavar a vossa própria sepultura." 
As mensagens no Panfleto eram contundentes. Os textos publicados na edição de 23 de março exigiam a revisão constitucional e evidenciavam o enfrentamento ao Congresso Nacional. A defesa do Panfleto dos marinheiros rebelados e o artigo de Paulo Lemos, ameaçando o Poder Legislativo, ambos publicados no dia 30 de março de 1964, desmoralizavam a hierarquia e a disciplina nas Forças Armadas. Os textos alimentaram a imagem de que havia um processo revolucionário em andamento, com o agravante de obter o respaldo do presidente da República

\section{Palavras finais: sociedade, democracia e reformas}

Historiadores, sociólogos e cientistas políticos dedicaram-se a estudar o processo que resultou no golpe que depôs João Goulart. As direitas foram muito pesquisadas, sobretudo porque foram elas que patrocinaram e desferiram o golpe de Estado. Sob vários ângulos, dos civis ou dos militares, das instituições ou da sociedade civil, são diversas as pesquisas que comprovaram a conspiração direitista. As esquerdas, por sua vez, não receberam a mesma atenção.

Quando se pesquisam as esquerdas naquela época, as fontes são eloquentes - e Panfleto, nesse sentido, é um documento estratégico. As esquerdas se expressavam por meio de organizações, movimentos e partidos políticos. Tinham líderes e programas. Em certo momento, formaram uma frente com o objetivo de aumentar suas forças. Lutavam por reformas que exigiam mudanças na Constituição. Como a estratégia preferencial que adotaram era extraparlamentar, criava-se uma tensão com as instituições, sobretudo com o Congresso Nacional. Outra questão presente nos textos é o menosprezo manifestado pela democracia-liberal. Os depoimentos estão repletos de menções à necessidade de implantar uma "democracia autêntica", uma "democracia verdadeira", embora tais expressões 
nunca fossem claramente definidas. O que se lê em entrevistas, artigos e editoriais é o desprezo pelo regime da Carta de 1946 e pelas instituições da democracia-liberal.

Contudo, isso não significa dizer que se tratava de uma "esquerda golpista". Tal interpretação foi formulada pelos que, de fato, golpearam as instituições. $\mathrm{Na}$ versão dos militares vitoriosos com o golpe, "1964 é visto como um contragolpe ao golpe de esquerda que viria, provavelmente assumindo a feição de uma 'república sindicalista' ou 'popular"' (D'ARAUJO, SOARES e CASTRO, 1994, p. 12). O argumento foi utilizado pelas direitas, sobretudo após o comício de 13 março, e reafirmado com o envio da Mensagem presidencial ao Congresso e a crise militar na Marinha. Mas não há nenhuma prova documental que garanta que as esquerdas reunidas na FMP planejavam um golpe de Estado. Também não há prova sobre as acusações de que Jango pretendia liderar tal golpe.

No entanto, não se pode desconhecer uma questão difícil: por que as direitas afirmaram que havia um plano golpista das esquerdas, de Jango e de Brizola, e por que os liberais e importantes forças políticas de centro acreditaram nessa versão? Algumas respostas estão a nosso dispor. Por exemplo, a Mensagem de Goulart enviada ao Congresso Nacional, propondo que fosse permitida sua reeleição e o direito de exercer, ao mesmo tempo, prerrogativas do Executivo e do Legislativo, deram argumentos aos seus opositores para afirmar que se tratava de um plano golpista. A proposta de concessão de voto aos analfabetos alimentou ainda mais a versão, porque beneficiaria o partido do presidente da República. É necessário considerar ainda algo ausente das análises: a FMP, após 13 de março, tornou-se a base política do governo Goulart, exigindo um governo exclusivo das esquerdas, o que implicava excluir da representação no Estado todas as outras expressões políticas. Por fim, a palavra "revolução" era comum nos textos e nos discursos de líderes esquerdistas. 
Embora as esquerdas não tivessem como objetivo dar um golpe de Estado - assim como as direitas fizeram -, manifestaram desprezo pelas instituições da democracia-liberal; atacaram o Congresso Nacional, instituição qualificada de "reacionária", e definiram a Constituição de 1946 como "ultrapassada". Privilegiaram a ação direta como luta política, sobretudo por meio de comícios, e defenderam a convocação de uma Assembleia Nacional Constituinte. Comícios e Constituinte são instrumentos democráticos de luta, sem dúvida, mas o resultado mais imediato naquela conjuntura política, particularmente no último caso, seria o rompimento com as instituições vigentes e com a Carta de 1946.

Portanto, se não havia planos de golpe de Estado, como as direitas perpetraram, estava em curso um projeto de rompimento institucional e o estabelecimento de um governo exclusivo das esquerdas. Tudo isso deu argumentos aos conspiradores de direita; tudo isso alimentou as versões que aludiam ao iminente golpe das esquerdas, de Brizola e de Jango; tudo isso, para usar um jargão muito conhecido, "fez o jogo" ou "deu armas para a direita".

A questão a se formular é a seguinte: havia interesse da sociedade brasileira em romper com as instituições da Constituição de 1946? Existem diversos indícios para responder à pergunta. Durante o comício da Central do Brasil, por exemplo, uma equipe de pesquisadores profissionais realizou pesquisa de opinião com o público presente no evento. O resultado demonstrou que $95 \%$ das pessoas apresentavam pensamento legalista e reformista: queriam eleições presidenciais em 1965 e as reformas de base, mas não admitiam o fechamento do Congresso Nacional e a reeleição de Goulart (NETO et alli, 1964, p. 37-38).

Outras pesquisas igualmente confirmam que o sentimento reformista e legalista expressado no comício da Central fazia parte de um universo bem mais amplo. Antonio Lavareda, por exemplo, trabalhou com pesquisas de opinião pública do IBOPE. Alguns dados são muito expressivos e reveladores. Em pesquisa realizada 
entre 9 e 26 de março de 1964, em oito capitais brasileiras, a seguinte pergunta foi formulada: "Na sua opinião, é ou não é necessária a realização de uma reforma agrária no Brasil?” (LAVAREDA, 1999, p. 177) Para 72\% dos entrevistados, a resposta foi positiva; para 11\%, foi negativa; $16 \%$ não souberam responder. É importante observar que a opinião favorável à reforma agrária foi positiva em todas as classes sociais, incluindo os ricos e as classes médias (62\% na cidade de São Paulo). Em outra pesquisa, realizada nos meses de junho e julho de 1963, em dez capitais do país, os pesquisadores do IBOPE ofereceram três opções políticas aos entrevistados. A pergunta era a seguinte: "Destas três hipóteses, qual é, a seu ver, a mais indicada para ser adotada pelo governo do Brasil?" (LAVAREDA, 1999, p. 176). A primeira opção era chamada de "direita" e seus representantes eram Carlos Lacerda e Ademar de Barros. A segunda era chamada de "centro" e os nomes relacionados eram Magalhães Pinto e Juscelino Kubitschek. A terceira era chamada de "esquerda" e os nomes citados eram Leonel Brizola e Miguel Arraes. Do total de entrevistados, 45\% se identificaram com o "centro", 23\% com a "direita", 19\% com a "esquerda" e 13\% não souberam responder. Respaldado por múltiplos dados, Lavareda afirma que, em meio à crescente polarização das lideranças de esquerda e de direita, "a opinião pública brasileira estava ancora$\mathrm{da}$, em sua maioria, ao centro". Centro que, para o autor, apoiava políticas reformistas: "o governo gozava de simpatia e razoável credibilidade. As principais reformas poderiam vir a ser viabilizadas com seu apoio" (LAVAREDA, 1999, p. 179-180).

Outro indício também aponta para a tendência reformista e legalista presente na sociedade brasileira. As esquerdas obtiveram grandes vitórias quando mobilizaram a sociedade pela defesa da legalidade, como ocorreu em agosto/setembro de 1961, com a luta pela manutenção da ordem jurídica e democrática. Naquele episódio, as esquerdas e os grupos nacionalistas defenderam a ordem legal. O movimento, portanto, era defensivo. Os setores direitistas, 
por sua vez, ao pregarem abertamente o golpe de Estado e a alteração da Constituição pela força, perderam a legitimidade. Ou seja, em 1961, a vitória foi das esquerdas, mas a luta era pela legalidade. Processo similar ocorreu no plebiscito que, em janeiro de 1963, garantiu a Goulart os poderes presidencialistas. As esquerdas, naquele momento, defenderam as prerrogativas constitucionais que foram usurpadas da sociedade em setembro de 1961. Mas, nos primeiros meses de 1964, sob o impacto de movimentos revolucionários que ocorriam em várias partes do mundo, Cuba em particular, os projetos das esquerdas, segundo Daniel Aarão Reis, eram de ruptura. As esquerdas estavam longe da plataforma de resistência de agosto de 1961. "A posição defensiva, de defesa da legalidade metamorfoseara-se em posição ofensiva, e, se fosse o caso, contra a lę" (AARÃO REIS, 2004, p. 36).

Os episódios da Campanha da Legalidade e do plebiscito, bem como a pesquisa durante o comício de 13 de março e as do IBOPE, são indícios que apontam para duas questões valorizadas pela sociedade brasileira na época: a necessidade das reformas e a preservação da legalidade democrática - dimensões da vida social que não eram compreendidas como excludentes entre si. Quando, no fim de 1963 e início de 1964, as esquerdas passaram a menosprezar e a questionar os fundamentos da democracia liberal, instituídos pela Constituição de 1946, seus apelos não encontraram respaldo na sociedade. Para Lavareda, o acirramento dos conflitos ideológicos não teve força suficiente para cindir a sociedade brasileira em pólos antagônicos, esvaziando o centro político. "A radicalização, que terminaria por destruir a ordem constitucional, era apenas uma opção estratégica das elites desinteressadas do jogo democrático." (LAVAREDA, 1999, p. 11-12).

As esquerdas em 1964 foram ousadas. Formularam um projeto ofensivo e de poder. Alcançaram, inclusive, o poder. Mas não tinham a força que imaginavam e declaravam ter. Lutaram por reformas, mas acusavam as instituições da Carta de 1946 de impedir a sua 
efetivação. Foram necessárias experiências muito duras sob a ditadura civil-militar para que se compreendesse, nas palavras de Adam Przeworski, que "a democracia não é um 'contrato social' sustentado por alguém que está fora do jogo. A democracia dura apenas se é tornada duradoura pelas partes em conflito" (FIGUEIREDO, 1993, p. 16).

\section{Left-wing on Panfleto. The political crisis of 1964 in the Popular Mobilization Front Newspaper}

Abstract: Since the beginning of President João Goulart's government, parties, movements and left-wing organizations joined for a political program known as "base reforms". In early 1963, the left-wing parties founded the Popular Mobilization Front (PMF), under the leadership of Leonel Brizola. The national-revolutionary group, which followed the Brizola's ideal in Brazilian Labor Party (BLP), had its own newspaper: Panfleto, the newspaper of street man. But this publication was also PMF's spokesman. Through their own means of communication, the leftwing groups, which acknowledged Brizola's leadership, expressed their ideas, projects and strategies. The purpose of this article is to resume ideas and political projects of left-wing groups joined to PMF and published on Panfleto from February 17, day of its first issue, and March 30,1964, when the last issue was published - of a total of seven numbers. These two months were critical during the crisis, which destabilized Goulart's government, when left-wing groups pro-reform became more and more radical, and the right-wing groups were against these changes.

Keywords: Panfleto, the newspaper of street man. Popular Mobilization Front. Political crisis in 1964. João Goulart's Government. Base reformation.

\section{Notas}

${ }^{1}$ Panfleto. O jornal do homem da rua. Rio de Janeiro, 17 de fevereiro de 1964, p. 13. As citações seguintes, até a nota 2 , encontram-se na mesma edição e página de Panfleto. ${ }^{2}$ Idem, 9 de março de 1964, p. 31.

${ }^{3}$ Panfleto, 24 de fevereiro de 1964, p. 6 e 7. As citações seguintes, até a nota 4, encontram-se na mesma edição e página de Panfleto.

${ }^{4}$ Idem, 9 de março de 1964, p. 7. 
${ }^{5}$ Panfleto, 24 de fevereiro de 1964, p. 9 . Em 11 de setembro de 1963, o Supremo Tribunal Federal considerou inelegíveis os sargentos eleitos no ano anterior. Em Brasília, os sargentos, em assembleia, decidiram realizar um "protesto armado", pretexto para desencadear uma insurreição de âmbito nacional. Depois de obstruírem as rodovias, dominaram o aeroporto civil, o Serviço de Rádio-Patrulha do Departamento Federal de Segurança Pública no Ministério da Justiça, a Central Telefônica, a Base Aérea e o Grupamento de Fuzileiros Navais. O mesmo ocorreu com o Congresso Nacional e o Supremo Tribunal Federal. A seguir, convocaram todas as unidades militares do país a aderirem ao movimento. Os comunicados eram assinados pelo "Comando Revolucionário de Brasília". Ver PARUCKER, 1992.

** Na linguagem dos sargentos daquela época, "instrumentos de trabalho" eram os fuzis.

As citações seguintes, até a nota 6, encontram-se na mesma edição e página de Panfleto. ${ }^{6}$ Panfleto, 23 de março de 1964, op. cit., p. 25.

${ }^{7}$ Idem, 2 de março de 1964, p. 13.

${ }^{8}$ Idem, 16 de março de 1964, p. 28.

${ }^{9}$ Panfleto, 16 de março, p. 6. As citações seguintes, até a nota 10, encontram-se na mesma edição e página de Panfleto

${ }^{10}$ Panfleto, 2 de março de 1964, p. 7. As citações seguintes, até a nota 11, encontramse na mesma edição e página de Panfleto.

${ }^{11} \mathrm{Idem}, 17$ de fevereiro de 1964, p. 21.

${ }^{12}$ Idem, 24 de fevereiro de 1964, p. 9.

${ }^{13}$ Idem, 2 de março de 1964, p. 21.

${ }^{14}$ Panfleto, 17 de fevereiro de 1964, editoral "A Carta de Vargas", p. 2. As citações seguintes, até a nota 15, encontram-se na mesma edição e página de Panfleto

${ }^{15}$ Idem, 9 de março de 1964, editorial "Lacerda: subproduto da conciliação", p. 2 e 3.

${ }^{16}$ Idem, p. 33. A citação seguinte é da mesma fonte.

${ }^{17}$ Idem, 23 de março de 1964, p. 30.

${ }^{18}$ Idem, 30 de março de 1964, p. 9.

${ }^{19}$ Panfleto, 24 de fevereiro de 1964, p. 28. As citações seguintes, até a nota 20, encontram-se na mesma edição e página de Panfleto

${ }^{20}$ Idem, 9 de março de 1963 , p. 8.

${ }^{21}$ Idem, p. 8.

${ }^{22}$ Idem, 16 de março de 1964, p. 25.

${ }^{23}$ Idem. 17 de fevereiro de 1964, p. 10-12. As citações seguintes, até a nota 24, encontram-se na mesma edição e página de Panfleto

${ }^{24}$ Idem, p. 28.

${ }^{25}$ Idem, 16 de março de 1964, p. 4.

${ }^{26}$ Panfleto, Editorial "Povo e governo", p. 2-3. As citações seguintes, até a nota 27, encontram-se na mesma edição e página de Panfleto

${ }^{27}$ Idem, p. 8.

Anos 90, Porto Alegre, v. 16 n. 29, p. 81-124, jul. 2009 
${ }^{28}$ João Goulart. Mensagem ao Congresso Nacional remetida pelo Presidente da República na abertura da sessão legislativa de 1964. Brasil, Brasília. In idem, 16 de março de 1964, p. 10-11. A íntegra do texto pode ser consultada em http://brazil. crl.edu/bsd/bsd/u1346/000002.html

${ }^{29}$ Panfleto, 23 de março, Op. cit., p. 6.

${ }^{30}$ Idem, 30 de março de 1964, p. 4 e 5.

${ }^{31}$ Idem, p. 7.

\section{Referências}

AARÃO REIS, Daniel. Ditadura e sociedade: as reconstruções da memória. In: AARÃO REIS, Daniel; RIDENTI, Marcelo; MOTTA, Rodrigo Patto Sá (Orgs.). O golpe e a ditadura militar 40 anos depois (1964-2004). Bauru/São Paulo: Edusc, 2004, p. 29-52.

AXT, Gunter (Org.). As guerras dos gaúchos. História dos conflitos do Rio Grande do Sul. Porto Alegre: Nova Prova Editora, 2008.

BALDISSERA, Marli de Almeida. Onde estão os grupos de onære? Os comandos nacionalistas na região Alto Uruguai-RS. Passo Fundo: UPF, 2005.

D'ARAÚJO, Maria Celina. Sindicatos, carisma e poder. O PTB de 1945-65. Rio de Janeiro: FGV, 1996.

D'ARAÚJO, Maria Celina; SOARES, Gláucio Ary D.; CASTRO, Celso (Orgs.). Visões do golpe. A memória militar sobre 1964. Rio de Janeiro: Relume-Dumará, 1994.

FERREIRA, Jorge. "O governo Goulart e o golpe civil-militar de 1964". In: FERREIRA, Jorge e DELGADO, Lucilia de Almeida Neves. O Brasil Republicano. O tempo da experiência democrática, v. 3. Rio de Janeiro: Editora Civilização Brasileira, 2003.

FERREIRA, Jorge. "A estratégia do confronto: A Frente de Mobilização Popular". In: Revista Brasileira de História, São Paulo: Anpuh, v. 24, n. 47, jan-jun. 2004.

FICO, Carlos. Além do golpe. Versões e controvérsias sobre 1964 e a Ditadura Militar. Rio de Janeiro: Record, 2004.

FIGUEIREDO, Argelina Cheibub. Democracia ou reformas; alternativas democráticas à crise politica 1961-1964, São Paulo: Paz e Terra, 1993.

GOMES, Angela de Castro e FERREIRA, Jorge. Jango, as múltiplas faces. Rio de Janeiro: Editora da Fundação Getúlio Vargas, 2007. 


\section{Esquerdas no Panfleto...}

GOMES, Angela de Castro. Trabalhismo e democracia: o PTB sem Vargas. In: GOMES, Angela de Castro (Org.). Vargas e a crise dos anos 50. Rio de Janeiro: Relume-Dumará, 1994.

LAVAREDA, Antônio. A democracia nas urnas. O processo partidário-eleitoral brasileiro (1945-1964). Rio de Janeiro: IUPERJ/Revan, 1999.

MORAES, Denis. A esquerda e o golpe de 64. Rio de Janeiro: Editora Espaço e Tempo, 1989.

MOTTA, Rodrigo Patto Sá. Em guarda contra o perigo vermelho. São Paulo: Perpectiva/ FAPESP, 2002.

NETO, Araújo et alli. Os idos de marro e a queda de abril. Rio de Janeiro: José Álvaro, 1964.

NEVES, Lucília de Almeida. PTB. Do getulismo ao reformismo (1945-1964). São Paulo: Marco Zero, 1989.

PARUCKER, Paulo E. C. Praças em pé de guerra. O movimento político dos subalternos militares no Brasil, 1961-1964. Niterói: PPGH/ICHF/UFF, dissertação de mestrado, 1992.

SALDANHA, Alberto. A UNE e o mito do Poder Jovem. Maceió: EDUFAL, 2005.

SCHILLING, Paulo. Como se coloca a direita no poder. 1. Os protagonistas. São Paulo: Global Editora, 1979. 